\title{
Observations and simulations of a wind farm modifying a thunderstorm outflow boundary
}

\author{
Jessica M. Tomaszewski ${ }^{1}$ and Julie K. Lundquist ${ }^{1,2}$ \\ ${ }^{1}$ Department of Atmospheric and Oceanic Sciences, University of Colorado, Boulder, CO 80309-0311, USA \\ ${ }^{2}$ National Wind Technology Center, National Renewable Energy Laboratory, Golden, CO 80401-3305, USA
}

Correspondence: Jessica M. Tomaszewski (jtomaszewski@ resurety.com)

Received: 8 April 2020 - Discussion started: 4 May 2020

Revised: 25 October 2020 - Accepted: 26 October 2020 - Published: 4 January 2021

\begin{abstract}
On 18 June 2019, National Weather Service (NWS) radar reflectivity data indicated the presence of thunderstorm-generated outflow propagating east-southeastward near Lubbock, Texas. A section of the outflow boundary encountered a wind farm and then experienced a notable reduction in ground-relative velocity, suggesting that interactions with the wind farm impacted the outflow boundary progression. We use the Weather Research and Forecasting model and its wind farm parameterization to address the extent to which wind farms can modify the near-surface environment of thunderstorm outflow boundaries. We conduct two simulations of the June 2019 outflow event: one containing the wind farm and one without. We specifically investigate the outflow speed of the section of the boundary that encounters the wind farm and the associated impacts on near-surface wind speed, moisture, temperature, and changes to precipitation features as the storm and associated outflow pass over the wind farm domain. The NWS radar and nearby West Texas Mesonet surface stations provide observations for validation of the simulations. The presence of the wind farm in the simulation clearly slows the progress of the outflow boundary by over $20 \mathrm{~km} \mathrm{~h}^{-1}$, similar to what was observed. Simulated perturbations of surface wind speed, temperature, and moisture associated with outflow passage were delayed by up to 6 min when the wind farm was present in the simulation compared to the simulation without the wind farm. However, impacts on precipitation were localized and transient, with no change to total accumulation across the domain.
\end{abstract}

Copyright statement. This work was authored (in part) by the National Renewable Energy Laboratory, operated by Alliance for Sustainable Energy, LLC, for the US Department of Energy (DOE) under contract no. DE-AC36-08GO28308. Funding was provided by the US Department of Energy Office of Energy Efficiency and Renewable Energy Wind Energy Technologies Office. The views expressed in the article do not necessarily represent the views of the DOE or the US Government. The US Government retains and the publisher, by accepting the article for publication, acknowledges that the US Government retains a nonexclusive, paid-up, irrevocable, worldwide license to publish or reproduce the published form of this work, or allow others to do so, for US Government purposes.

\section{Introduction}

Wind energy deployment is growing rapidly to provide a near-zero emissions source of electricity that can meet increasing energy demands. The International Energy Agency (IEA) predicts wind energy will reach $14 \%$ of global capacity $(\sim 1700 \mathrm{GW})$ by 2040 (IEA, 2018). Wind turbines generate electricity by using momentum from the wind to turn their blades and generator, causing a downwind wake characterized by an increase in turbulence and reduction in wind speed (Lissaman, 1979). Groups of turbines will then generate an aggregate wind farm wake, which has been observed to extend over $50 \mathrm{~km}$ downwind of a wind farm, particularly during stable conditions, when little atmospheric turbulence is present to erode the wake (Christiansen and Hasager, 2005; Platis et al., 2018). 
Wind farm wakes have been observed to impact their ambient environment, particularly at night via turbine-induced mixing of the nocturnal inversion. Baidya Roy and Traiteur (2010) first used in situ observations within a wind farm to identify that a net downward transport of warm air at night causes a statistically significant increase in surface temperature in stably stratified boundary layers. Further in situ measurements of lidar profiles and surface fluxes from the Crop Wind Energy Experiment (CWEX) over an Iowa utility-scale wind farm indicate that turbines modify the flow fields and surface heat flux above and below the rotor layer, causing average transient surface temperature increases between 0 and $0.5 \mathrm{~K}$ overnight, reaching $1.5 \mathrm{~K}$ in some cases (Rajewski et al., 2013, 2014, 2016). Another field campaign by Smith et al. (2013) in a large wind farm in the United States Midwest identifies a strong surface warming (1 to $1.5 \mathrm{~K}$ ) in the wake of the wind farm at night, with no substantial warming or cooling signals during the daytime. Armstrong et al. (2016) find that operational wind turbines raised nighttime air temperature by $0.18 \mathrm{~K}$ and absolute humidity by $0.03 \mathrm{~g} \mathrm{~m}^{-3}$ at a peatland wind farm in Scotland. Satellitederived analyses also report surface warming (up to $1 \mathrm{~K}$ ) within wind farms and also up to $5 \mathrm{~km}$ downwind (Zhou et al., 2012; Xia et al., 2016). In situ airborne measurements of offshore wind farms also find temperature increases of $0.5 \mathrm{~K}$ and water vapor decreases of $0.5 \mathrm{~g} \mathrm{~kg}^{-1}$ in the rotor layer downwind during stably stratified conditions (Platis et al., 2018; Siedersleben et al., 2018a). Measurements from two $120 \mathrm{~m}$ tall towers in Iowa detect differences in the timing of nocturnal transitions due to the presence of a wind farm, where a single turbine wake decoupled the turbulent connection between the surface and above the wind turbine, accelerating the onset of near-surface stabilization by a few hours and lengthening the transition period by up to an hour (Rajewski et al., 2020).

Due to sparse data from operational wind farms, modeling studies are often used to examine local and regional impacts of existing and hypothetical wind farms. Baidya Roy (2004) conducted the first study within a coupled land-atmosphere mesoscale model, representing wind turbines as sinks of momentum and sources of turbulence to demonstrate that the simulated wind farm slows hub-height winds and generates turbulent eddies that enhance vertical mixing, leading to a warming and drying of the surface air. Wind turbines can also be represented numerically in mesoscale simulations by exaggerating surface roughness to represent the local reduction in wind speed of wind farm wakes (Keith et al., 2004; Frandsen et al., 2009; Barrie and Kirk-Davidoff, 2010; Fitch, 2015). This enhanced surface roughness approach was later shown to produce erroneous predictions, including the wrong sign of surface temperature change through the diurnal cycle (Fitch et al., 2013). Recent mesoscale modeling studies have used the turbine power and thrust curves to define the elevated momentum sink and turbulence generation of a simulated wind turbine (Fitch et al., 2012). The turbine power and thrust curves give the manufacturer-specified relationship between hub-height inflow wind speed, power generation, and force exerted onto the ambient air by a specific wind turbine. These specifications can better predict meteorological impacts of wind turbines from hub height to the surface and form the basis for multiple wind farm parameterizations in mesoscale numerical weather prediction models, including the Wind Farm Parameterization (WFP) (Fitch et al., 2012; Fitch, 2016).

The open-source WFP of the Weather Research and Forecasting (WRF) model collectively represents wind turbines in each model grid cell as a momentum sink and a turbulence source within the vertical levels intersecting the turbine rotor disk (Fitch et al., 2012; Fitch, 2016). The virtual wind turbines convert kinetic energy from the wind into power, which is reported as an aggregate sum in each model grid cell. The default setting of the WFP dictates that the turbine-induced turbulence generation is derived from the difference between the power and thrust coefficients, and this option must remain enabled to produce the vertical mixing necessary to attain the expected nocturnal surface warming (Tomaszewski and Lundquist, 2020). Users can adjust the specifications of the parameterized turbine, including its rotor diameter, hub height, thrust coefficients, and power curve as well as its latitude and longitude location. WFP simulations have been validated with power production data (Lee and Lundquist, 2017a) and airborne measurements of winds (Siedersleben et al., 2018b), temperature and moisture (Siedersleben et al., 2018a), and turbulence (Siedersleben et al., 2020) and have reproduced the observed localized, nighttime, near-surface warming produced by wind turbines mixing warmer air from the nocturnal inversion down to the surface (Fitch et al., 2013; Cervarich et al., 2013; Lee and Lundquist, 2017b; Xia et al., 2017, 2019). To our knowledge, the WRF WFP has not yet been applied to explore interactions between wind farms and transient phenomena like thunderstorm outflow boundaries.

A thunderstorm gust front, or outflow boundary, marks the advancing surface boundary of the outflow of an evaporatively cooled downdraft from a thunderstorm (e.g., Goff, 1976; Droegemeier and Wilhelmson, 1987). Outflow boundary passage is often associated with a significant change in surface meteorological conditions, including a sharp decrease in temperature, a pronounced wind direction shift, and damaging straight-line winds fueled by a strong horizontal pressure gradient across the outflow boundary line (Wakimoto, 1982). The propagation of outflow into a thermodynamically favorable ambient environment can initiate convection far from the source thunderstorm (Carbone et al., 1990), and the strong low-level wind shear associated with propagating outflows has caused several aircraft accidents (Zrnic and Lee, 1983) that would otherwise be unlikely in a typical wind farm wake environment (Tomaszewski et al., 2018). Outflow boundary motion is thus of interest in short- 
range severe weather and aviation forecasting and nowcasting.

Doppler radar observations can provide kinematic information of the full depth of thunderstorm outflow (e.g., Wakimoto, 1982; Klingle et al., 1987; Mueller and Carbone, 1987; Quan et al., 2014), with an outflow boundary's presence and ground-relative velocity often identified via a "fine line" in radar reflectivity. On 18 June 2019, around 01:00 UTC, National Weather Service radar reflectivity indicated the presence of thunderstorm-generated outflow propagating eastsoutheastward north of Lubbock, Texas. A section of the outflow boundary that encountered a wind farm experienced a notable reduction in speed, qualitatively suggesting that the wind farm impacted the outflow boundary progression.

Here, we use a numerical weather prediction mesoscale model capable of simulating outflow boundary movement to explore its interaction with a parameterized wind farm during the aforementioned June 2019 event. Numerical models have previously been utilized to gain insight into the life cycle and dynamics of thunderstorm outflow (e.g., Droegemeier and Wilhelmson, 1987) and more recently in the Weather Research and Forecasting model by Duda and Gallus (2013) and Nugraha and Trilaksono (2018) with success. The inclusion of a Wind Farm Parameterization (WFP) in WRF (e.g., Fitch et al., 2012; Fitch, 2016) to capture wind farm nearenvironment interactions makes this model a favorable tool for such a study considering the impacts wind farms may have on outflow boundaries and their resulting changes in temperature, wind, and precipitation.

We hypothesize that wind farms can modify transient and mesoscale features like thunderstorm outflow boundaries. Section 2 describes the case study and the model setup. Section 3 presents the modifications to the outflow progression by the wind farm and the impacts on surface temperature, winds, moisture, and precipitation. Section 4 summarizes our results, confirming that the WRF WFP and radar data capture the wind farm modifying the outflow.

\section{Methodology}

\subsection{Case description}

The 18-19 June 2019 outflow event near Lubbock, Texas, is highlighted in this study as the first known and archived case of an outflow boundary passing over and being modified by a wind farm, which was brought to our attention on social media by Jessie McDonald (@jmeso212). The event began with a cluster of thunderstorms propagating eastward over eastern New Mexico and the western Texas panhandle. These storms formed an organized mesoscale convective system (MCS) around 23:00 UTC on 18 June at the New MexicoTexas border and shifted to move southeastward. An outflow boundary originated from this MCS, visible as a fine line on NEXRAD WSR-88D displays beginning at approximately 23:40 UTC (Fig. 1a). This outflow boundary advanced south- eastward ahead of the MCS, eventually reaching the Hale wind farm at 00:50 UTC on 19 June. The wind farm can be detected on the radar display (Fig. 1a) as a cluster of speckled points of high reflectivity, indicative of the hard-target echoes of radar beams reflecting off of spinning turbines, known as wind turbine clutter (Isom et al., 2009). A defined notch appeared within the outflow boundary immediately following passage over the wind farm, suggesting a significant reduction in ground-relative velocity where the outflow encountered and interacted with the wind farm (Fig. 1b, c).

\subsection{Observations available}

The National Weather Service NEXRAD WSR-88D radar in Lubbock, Texas (KLBB), (Klazura and Imy, 1993) provides the initial visualization for this study of the outflow propagating and interacting with the wind farm during the June 2019 event. Level II radar data (e.g., base reflectivity, base velocity) are provided by the National Oceanic and Atmospheric Administration (NOAA) National Centers for Environmental Information (NOAA National Weather Service, 1991) at 4 min temporal resolution and quantify the speed and position of the outflow boundary throughout the event.

Surface observations are available through the West Texas Mesonet, a statewide observation network consisting of 40 automated surface meteorological stations that measure up to 15 meteorological parameters over an observation period of 5 min (Schroeder et al., 2005). Sampling intervals vary from 3 to $60 \mathrm{~s}$ depending on the sensor, and data are reported as $5 \mathrm{~min}$ averages centered on the $5 \mathrm{~min}$ period. A 5 min observation reporting time has been previously proven sufficient in resolving other density current passages (Toms et al., 2017). The Abernathy surface station is located $5 \mathrm{~km}$ southwest of the southwest corner of the wind farm in our study (gray diamond in Fig. 3) and provides $5 \mathrm{~min}$ resolution validation data of $1.5 \mathrm{~m}$ temperature, $10 \mathrm{~m}$ wind speed and direction, and $1.5 \mathrm{~m}$ humidity, among other variables, for the precursor outflow state prior to wind farm interaction for our simulations. We explored accessing meteorological information from the Hale wind farm and others in the vicinity, but those data are proprietary and not available.

\subsection{Simulations conducted}

We conduct the simulation composing our study with version 3.8.1 of the Advanced Research WRF (ARW) model (Skamarock and Klemp, 2008; Powers et al., 2017). We define a simulation with three nested domains with horizontal grid spacings of 27,9 , and $3 \mathrm{~km}$, respectively, where the innermost $3 \mathrm{~km}$ domain is centered over the wind farm and outflow event location (Fig. 2a). Our previous investigation (Tomaszewski and Lundquist, 2020) of the sensitivity of the WRF WFP to spatial resolution suggests that $3 \mathrm{~km}$ horizontal grid spacing is adequate for resolving the wind farm effects. Also based on the results of that study, which argue 

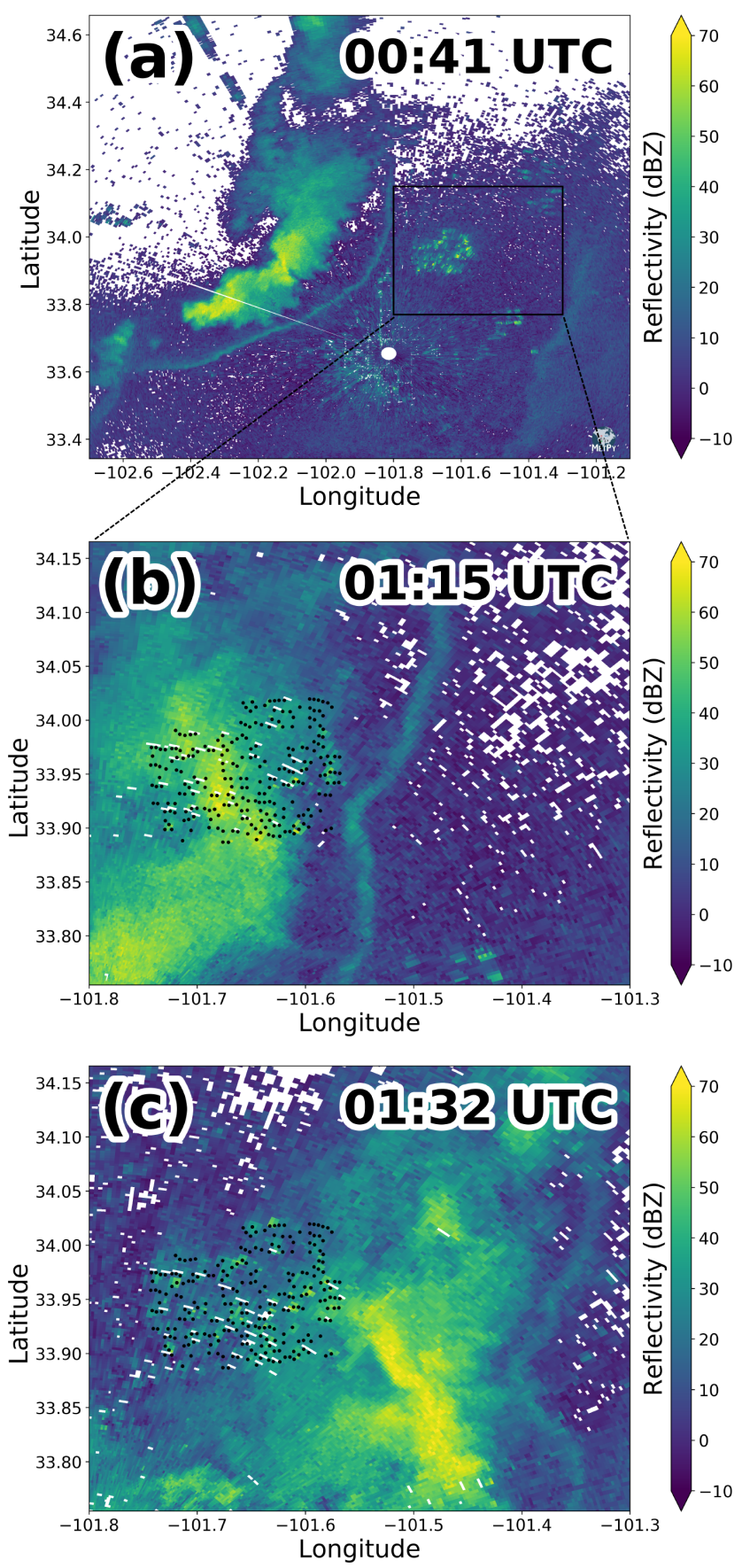

Figure 1. NEXRAD WSR-88D radar reflectivity from the Lubbock radar site (KLBB) (a) prior to the outflow boundary arriving at the wind farm, (b) immediately following outflow boundary passage over the wind farm, and (c) several minutes after passage. Panels (b) and (c) are zoomed in closer to better view the shape of the boundary, and that subset is denoted in panel (a) by the black box.

that the WFP requires fine vertical resolution near the surface, we set the vertical grid spacing to be $\sim 10 \mathrm{~m}$ in the lowest $200 \mathrm{~m}$ (Fig. 2b), stretching vertically thereafter for a total of 58 vertical levels between the surface and $170 \mathrm{hPa}$. The model time step is $30 \mathrm{~s}$ on the outer domain, refined by a factor of 3 for each nest. Turbine-induced turbulence is parameterized via a source of turbulent kinetic energy (TKE). The 0.7 ${ }^{\circ}$ ERA-Interim (ECMWF, 2009; Dee et al., 2011) data set provides initial and boundary conditions for the simulations, and topographic data are provided at $30 \mathrm{~s}$ resolution (nominally $0.8 \mathrm{~km}$ at this latitude). Physics options include the Dudhia shortwave radiation (Dudhia, 1989) with a $30 \mathrm{~s}$ time step, the Rapid Radiative Transfer Model longwave radiation scheme (Mlawer et al., 1997), a surface layer scheme that accommodates strong changes in atmospheric stability (Jimenez et al., 2012), the second-order Mellor-YamadaNakanishi-Niino planetary-boundary-layer scheme (Nakanishi and Niino, 2006) without TKE advection, land surface physics with the Noah Land Surface Model (Ek et al., 2003), the single-moment six-class microphysics scheme (Hong and Lim, 2006), and the explicit Kain-Fritsch cumulus parameterization (Kain, 2004) on domains with horizontal grid spacings coarser than $3 \mathrm{~km}$. We simulate the $6 \mathrm{~h}$ window around the time when the outflow passed over the wind farm (18 June 22:00 UTC to 19 June 04:00 UTC). We begin spinup $10 \mathrm{~h}$ prior, at 12:00 UTC on 18 June.

The US Geological Survey Turbine Database (Hoen et al., 2020) provides the latitude-longitude model input locations of the wind turbines at the Hale wind farm (Fig. 2c, d). We use power and thrust curves from the $1.5 \mathrm{MW}$ Pennsylvania State University generic turbine (Schmitz, 2012), based on the General Electric SLE turbine $(80 \mathrm{~m}$ hub height and $77 \mathrm{~m}$ rotor diameter). This turbine model closely matches the $2 \mathrm{MW}$ Vestas turbines actually installed at the Hale wind farm, and Siedersleben et al. (2018b) show little sensitivity to the exact turbine power curve. We assess the impact the wind farm has on the model solution of the outflow by comparing a simulation without the WFP to a simulation with the WFP, as in Fitch et al. (2012), Lee and Lundquist (2017a), Lundquist et al. (2018), and Redfern et al. (2019). We specifically investigate differences in the near-surface wind speed, temperature, moisture, and precipitation solutions between simulations with and without the wind farm as the storm and associated outflow pass over the wind farm domain.

\section{Results}

\subsection{Performance of WRF against observations}

The WRF simulation with the Wind Farm Parameterization (WFP) produces reasonable solutions of the thunderstorm outflow event on 18-19 June 2019. Three consecutive plan views of $2 \mathrm{~m}$ temperature within a section of the domain illustrate the outflow progression (Fig. 3). By 22:36 UTC on 18 June, a cold pool had developed from the thunderstorm downdraft, forming the outflow (Fig. 3a). This outflow propagated southeastward toward the wind farm, eventually passing over it by 23:22 UTC (Fig. 3b) and spreading further southeast by the end of the UTC day (Fig. 3c). 

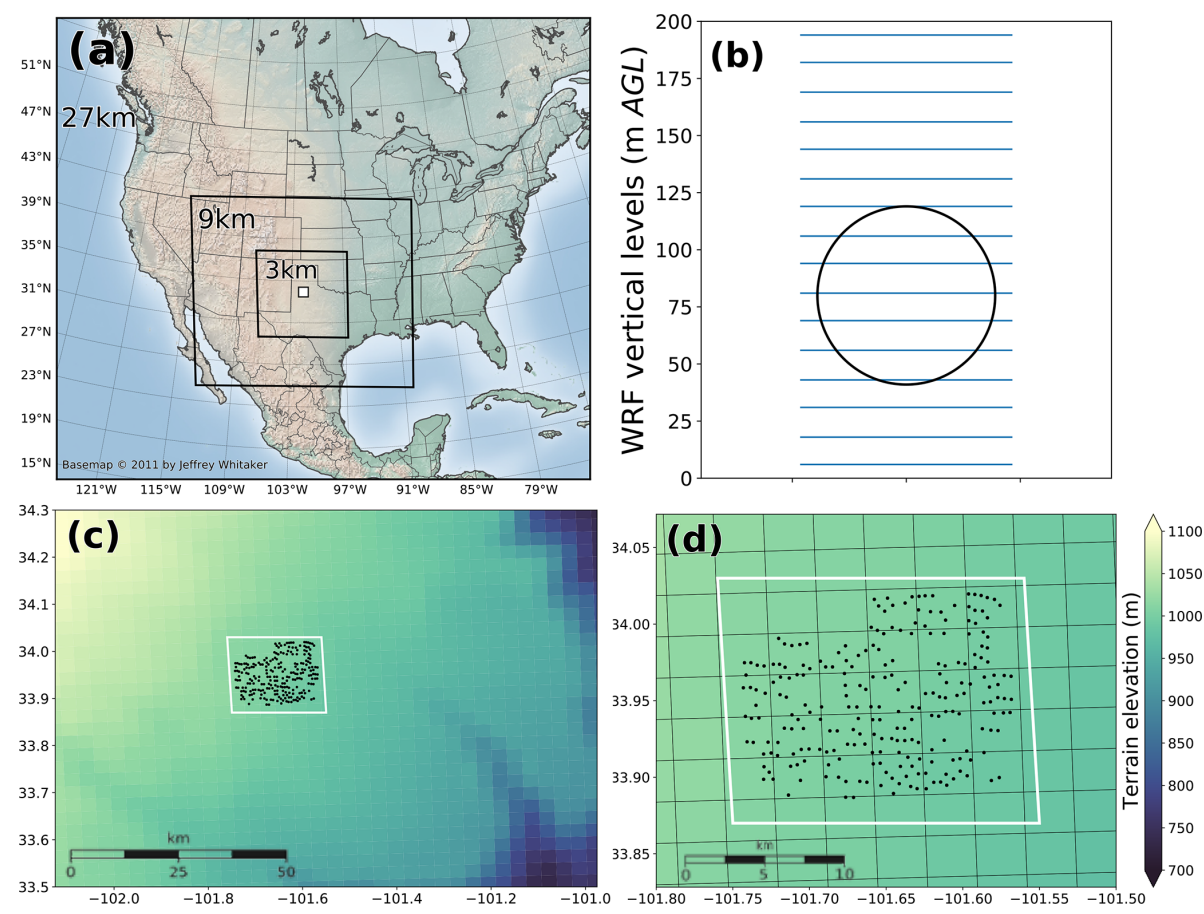

Figure 2. Maps representing (a) the nested domains for the simulations, with the Hale wind farm denoted by the white square, (b) the model vertical levels intersecting the simulated turbine rotor (black circle), (c) the topography around the Hale wind farm, and (d) the wind turbine layout over the same terrain contour as in (c). The white polygon in panels (c) and (d) denotes the approximate outline of the Hale wind farm. Geography data are provided by Matplotlib's (Hunter, 2007) Basemap @ Jeffrey Whitaker 2011.

The spatial coverage and shape of the outflow reasonably match the shape of the outflow boundary visible on radar (Fig. 1). However, the simulated moist convection and subsequent outflow boundary occurs too early. The simulated outflow passes over the wind farm location by 23:22 UTC on 18 June, whereas the radar indicates that this passage occurs around 01:15 UTC on 19 June, about $2 \mathrm{~h}$ later (Fig. 1b). This discrepancy could be caused by the boundary conditions or other model configuration choices, though as previously mentioned, the structures of the simulated and observed cold pools are similar and therefore the simulation suits the needs of the study.

To better understand WRF's skill in simulating the intensity of the outflow event, we plot a time series from the nearby Abernathy West Texas Mesonet surface station against that from the corresponding closest point in the model domain (gray triangle in Fig. 3). Model results are shifted ahead $2 \mathrm{~h}$ to allow for direct comparison between the simulation and observations during the outflow passage, as done in the Arthur et al. (2020) investigation of a frontal passage. The WRF simulation (solid lines in Fig. 4) predicts similar $10 \mathrm{~m}$ wind speeds as observed (dotted lines) before the passage in addition to an accurate magnitude of wind speed increase associated with the outflow arrival. The simulated winds remain elevated near $\sim 23 \mathrm{~m} \mathrm{~s}^{-1}$ for $15 \mathrm{~min}$ before decreasing close to the prefrontal state, whereas the surface station observations decrease almost immediately (Fig. 4a), possibly an artifact of the 5 min sampling in the observations as opposed to the $1 \mathrm{~min}$ sampling in the simulation, verified by plotting a $5 \mathrm{~min}$ average of the simulation results (dashed line in Fig. 4a). The simulation displays biases in the $2 \mathrm{~m}$ temperature and moisture precursor states (Fig. 4b, c). WRF initially has a $2.5 \mathrm{~K}$ warm bias, a $\sim 35 \%$ relative humidity (RH) dry bias, and $\sim 3 \mathrm{~g} \mathrm{~kg}^{-1}$ dry bias against the observations. These model biases could be due to inaccuracies in the soil moisture that stem from differences in precipitation that occurred earlier in the day. The magnitude of the $2 \mathrm{~m}$ temperature decrease (Fig. 4b) and moisture increases (Fig. 4c) due to the outflow arrival in WRF seem adequate, albeit slightly more intense than in the observations.

\subsection{Differences in outflow passage between wind farm and no wind farm simulations}

Having validated WRF's ability to adequately capture the outflow event, we next compare the two WRF simulations to assess the impact a parameterized wind farm has on the simulated outflow. Three instantaneous map views show the difference in $2 \mathrm{~m}$ temperature between the simulations, with the no wind farm (NWF) case subtracted from the Wind Farm Parameterization (WFP) case (Fig. 5). Regions of cooler temperatures (blue) indicate that the temperature in the WFP simulation is cooler than in the NWF simulation, suggesting faster movement of the outflow bringing cooler temperatures. 

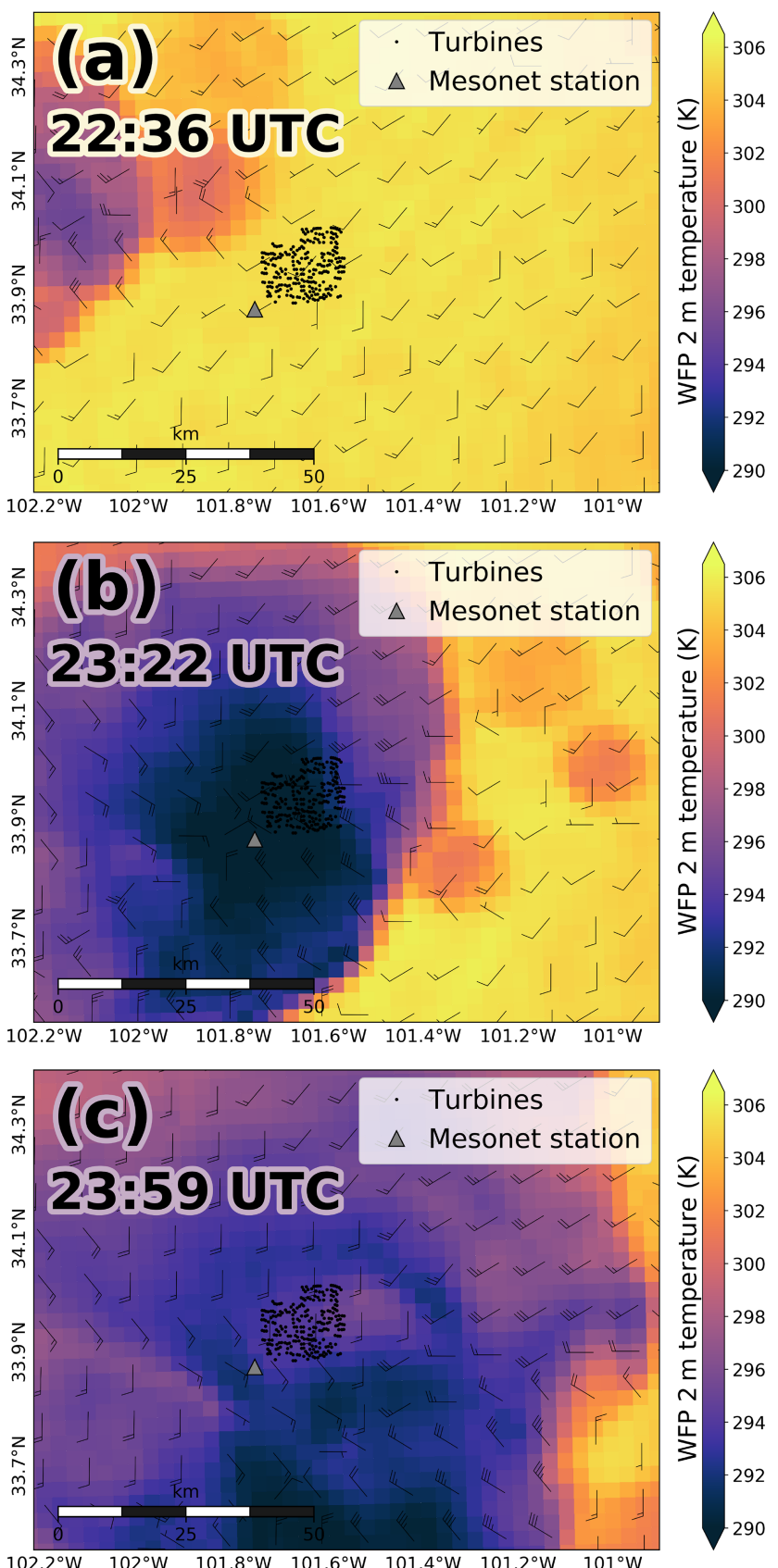

Figure 3. Snapshots of simulated $2 \mathrm{~m}$ temperatures from the Wind Farm Parameterization (WFP) simulation (a) prior to the outflow boundary arriving at the wind farm, (b) immediately following outflow boundary passage over the wind farm, and (c) several minutes after passage. Wind barbs are shown in knots.

Indeed, the dark wind barbs in Fig. 5 representing winds from the WFP simulation indicate stronger winds present (by 5$10 \mathrm{kn}$ ) in cooler (blue) regions than in the NWF simulation (light wind barbs). Conversely, red regions indicate warmer temperatures in the wind-farm-containing simulation, indicating that the outflow is moving slower in this simulation than in the NWF simulation. Early in the outflow event,
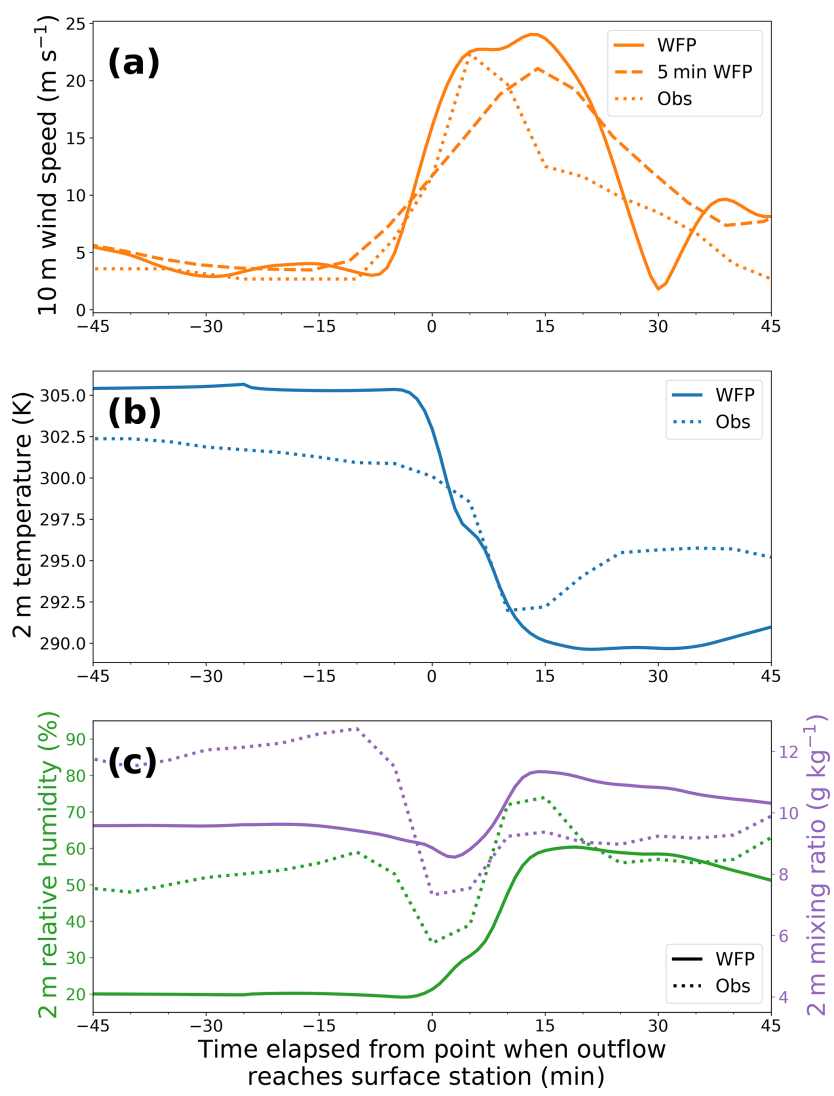

Figure 4. Time series comparing the Wind Farm Parameterization (WFP) simulation solutions against Mesonet surface station observations of (a) $10 \mathrm{~m}$ wind speed, (b) $2 \mathrm{~m}$ temperature, and (c) $2 \mathrm{~m}$ relative humidity and mixing ratio.

only subtle differences exist between the simulations upwind from the wind farm (Fig. 5a), likely arising from the generation of gravity waves (Smith, 2009; Allaerts and Meyers, 2018, 2019). These differences increase in magnitude after the outflow passes over the wind farm. A compact region of warmer temperatures (up to $8 \mathrm{~K}$ ) in the wind farm simulation emerges following outflow passage over the wind farm, indicating that interaction with the wind farm has caused that section of the advancing outflow to slow its speed (Fig. 5b). This region of slowed outflow expands in spatial area as the outflow progresses southeastward (Fig. 5c). A similar speed reduction is visible in the bent outflow shape of the radar observations (Fig. 1b, c). The cooler regions emerging on both sides of the wind during outflow passages suggest that flow is being redirected around the wind farm (Fig. 5b). A vertical cross section of the temperature difference between the simulations taken at 23:22 UTC (dashed line in Fig. 5b) shows that the wind farm (black X) impacts the outflow from the surface to $\sim 2 \mathrm{~km}$ (Fig. 6).

We next sample a point from both the WFP and NWF simulations downwind of the wind farm location (white diamond in Fig. 5) to assess how differences between the simula- 

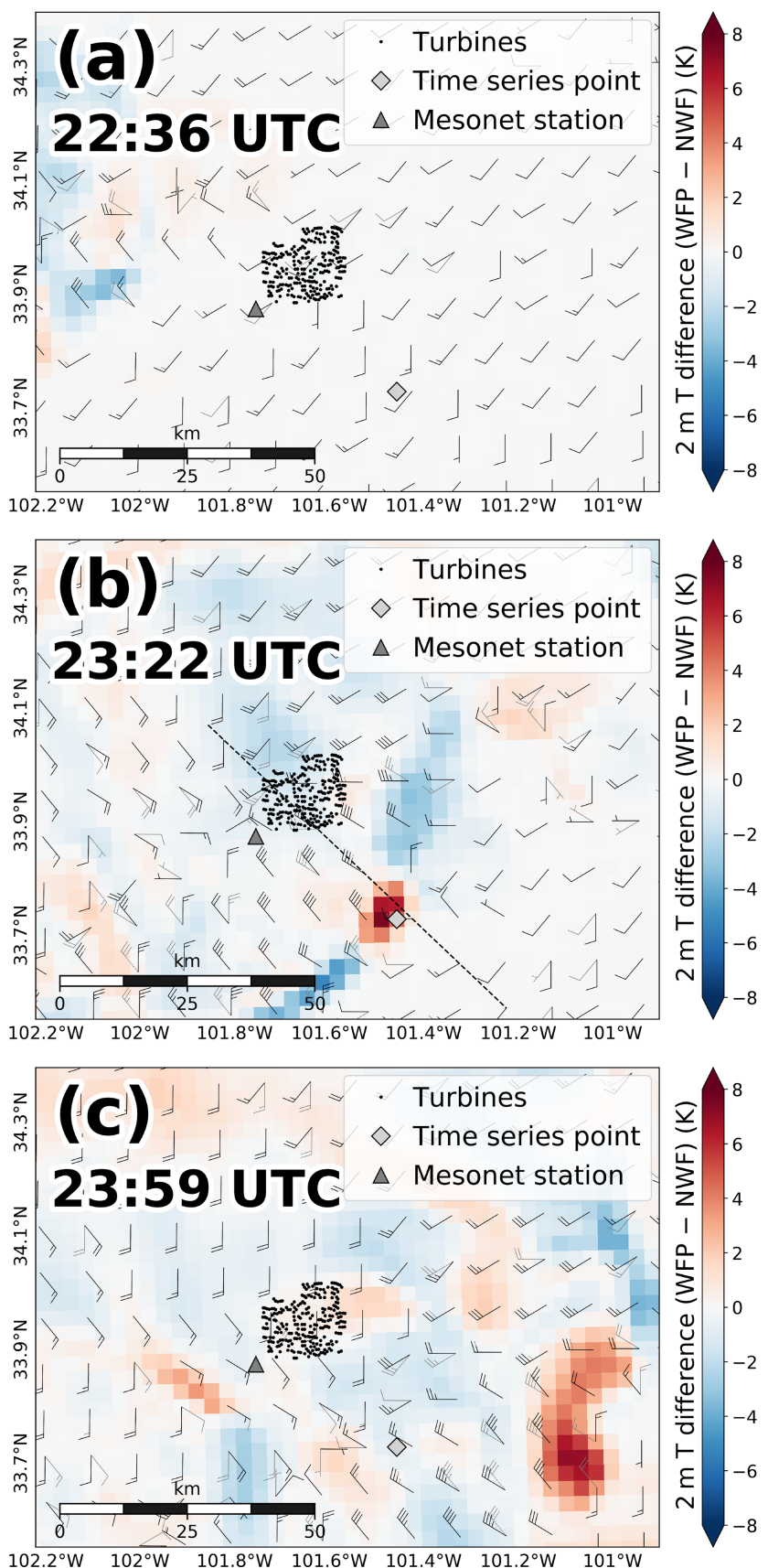

Figure 5. Snapshots of differences in $2 \mathrm{~m}$ temperature between the Wind Farm Parameterization (WFP) and no wind farm (NWF) simulations (a) prior to the outflow boundary arriving at the wind farm, (b) immediately following outflow boundary passage over the wind farm, and (c) several minutes after passage. Wind barbs are shown in knots, with the darker (lighter) barbs representing the WFP (NWF) winds. The dashed line in panel (b) indicates the location of the vertical cross section in Fig. 6.

tions evolve at that point following outflow passage (Fig. 7). Close agreement exists between the simulations across all variables plotted preceding arrival of the outflow. Upon the

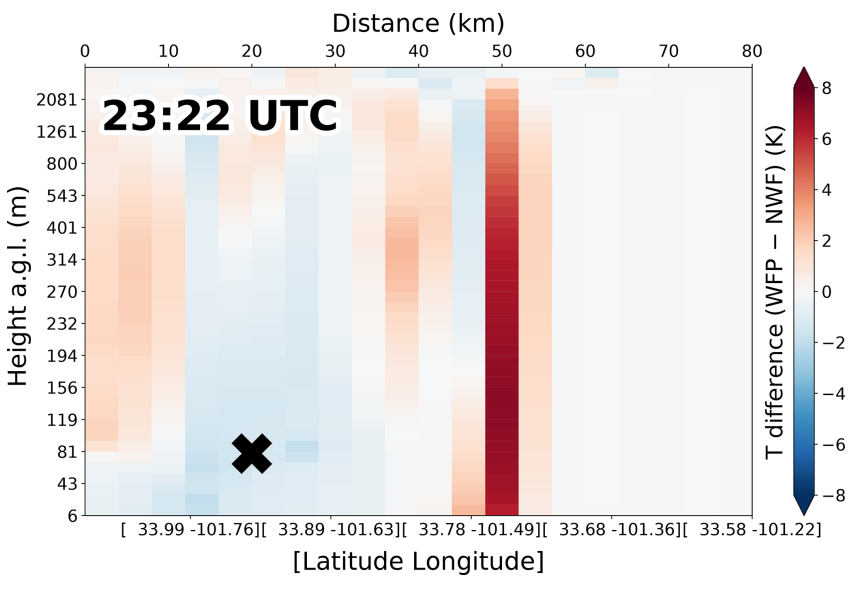

Figure 6. Vertical cross section of the temperature difference between the Wind Farm Parameterization (WFP) and no wind farm (NWF) simulations immediately following outflow boundary passage over the wind farm, corresponding to the dashed line in (Fig. 5b). Note the $y$-axis ticks are not spaced linearly due to the increasingly coarse vertical grid spacing at higher model levels.

arrival of the outflow, the $10 \mathrm{~m}$ wind speed increases first in the NWF simulation (dashed line), reaching a maximum of $\sim 30 \mathrm{~m} \mathrm{~s}^{-1}$. The WFP simulation (solid line) begins its outflow-induced increase a few minutes after the NWF simulation and attains a smaller initial wind speed maximum of $\sim 25 \mathrm{~m} \mathrm{~s}^{-1}$. A secondary pulse of increased wind speeds occurs in both simulation cases and reaches similar magnitudes, suggesting that the modified outflow in the wind farm case does not experience notable changes after the initial disruption by the wind farm (Fig. 7a).

The temporal evolution of the $2 \mathrm{~m}$ temperature is similar to that of the wind speed. The WFP and NWF simulations produce the same initial temperature until the WFP simulation diverges from the NWF simulation due to the windfarm-modified outflow approaching $\sim 3$ min later. The associated outflow cooling is of similar magnitude $(\sim 12.5 \mathrm{~K})$ between the simulations, but the WFP simulation reaches its minimum temperature $\sim 4$ min after the NWF simulation (Fig. 7b).

Differences in the $2 \mathrm{~m}$ relative humidity between the simulations evolve similarly to those in the $2 \mathrm{~m}$ temperature. Both simulations maintain a value near $\sim 20 \%$ until the passing outflow causes an increase up to $50 \%$, with the increase occurring for the WFP simulation 4-5 min after the NWF (green lines in Fig. 7c). The absolute moisture quantity ( $2 \mathrm{~m}$ mixing ratio, purple lines) reaches its peak in moisture $\left(10.5 \mathrm{~g} \mathrm{~kg}^{-1}\right) \sim 6$ min after the NWF does.

We corroborate the proxies for outflow ground-relative velocity in the time series of meteorological variables (Fig. 5) by directly quantifying the speed of the simulated and observed outflow boundaries (Fig. 8a). We measure the observed outflow speed by tracking the reflectivity fine line along a transect and recording its distance traveled every data 

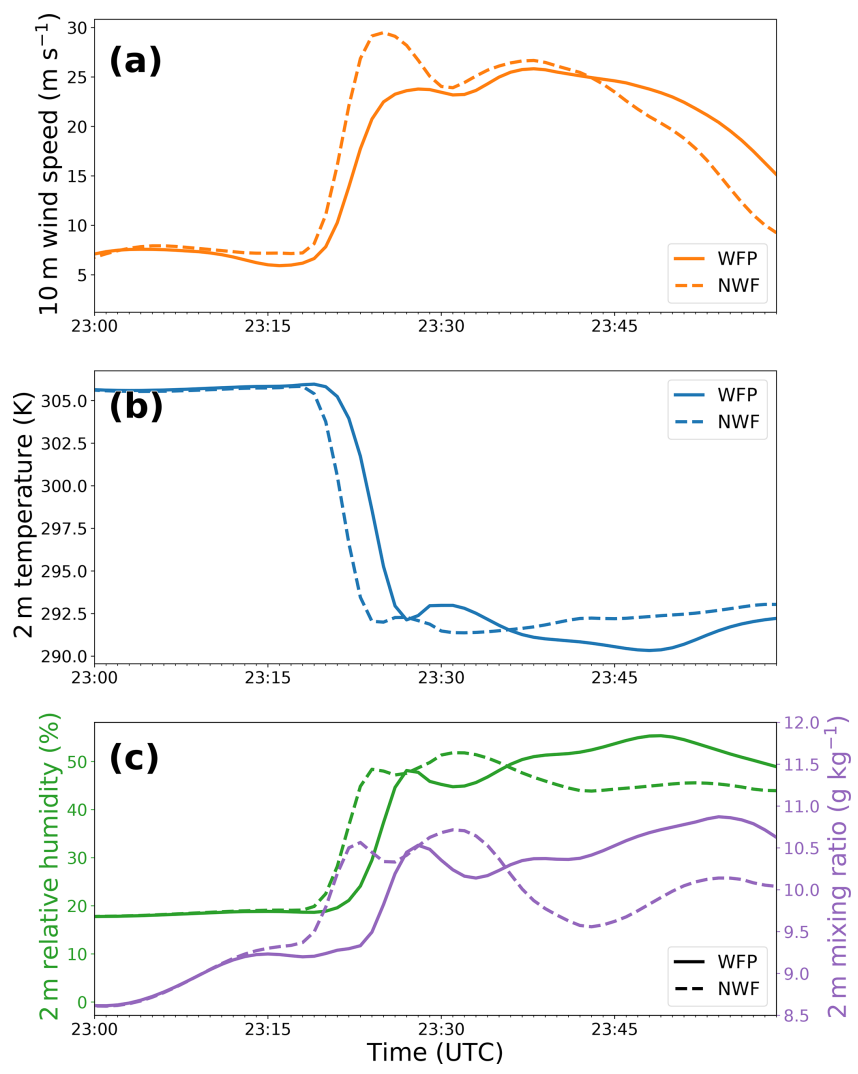

Figure 7. Time series comparing the Wind Farm Parameterization (WFP) and no wind farm (NWF) simulation solutions of (a) $10 \mathrm{~m}$ wind speed, (b) $2 \mathrm{~m}$ temperature, and (c) $2 \mathrm{~m}$ relative humidity and mixing ratio.

update (typically $4 \mathrm{~min})$. As the radar is southwest $\left(220^{\circ}\right)$ of the portion of the outflow boundary of interest, which is moving nearly to the southeast at a heading of $120^{\circ}$ (Fig. 1), we note that the feature therefore maintains an approximately constant distance to the radar and thus height above ground even as the feature moves, thus not impacting our calculations of ground-relative outflow speed.

Without a fine line present in the simulations to denote the outflow boundary, we choose to track the simulated outflow using the spatial gradient in wind speed, specifically the $\frac{4 \mathrm{~m} \mathrm{~s}^{-1}}{\mathrm{~km}}$ contour (e.g., Fig. 8b). The simulations are examined at $4 \mathrm{~min}$ intervals to match the temporal resolution of the radar data. Both simulation and radar outflow are measured against a $5 \mathrm{~km} \times 5 \mathrm{~km}$ grid to estimate distance traveled (see Fig. 8b). The transect along which we measure distance traveled is oriented to track through the wind farm and the region of maximum outflow distortion by the wind farm. Three separate measurements are conducted for each case (i.e., radar, WFP simulation, and NWF simulation) to account for human error. Each examination is conducted 3 times the same way by the same person over the same transect to generate multiple estimates of outflow speed. Conducting this qualitative measurement is a dynamic process, and once a point on the
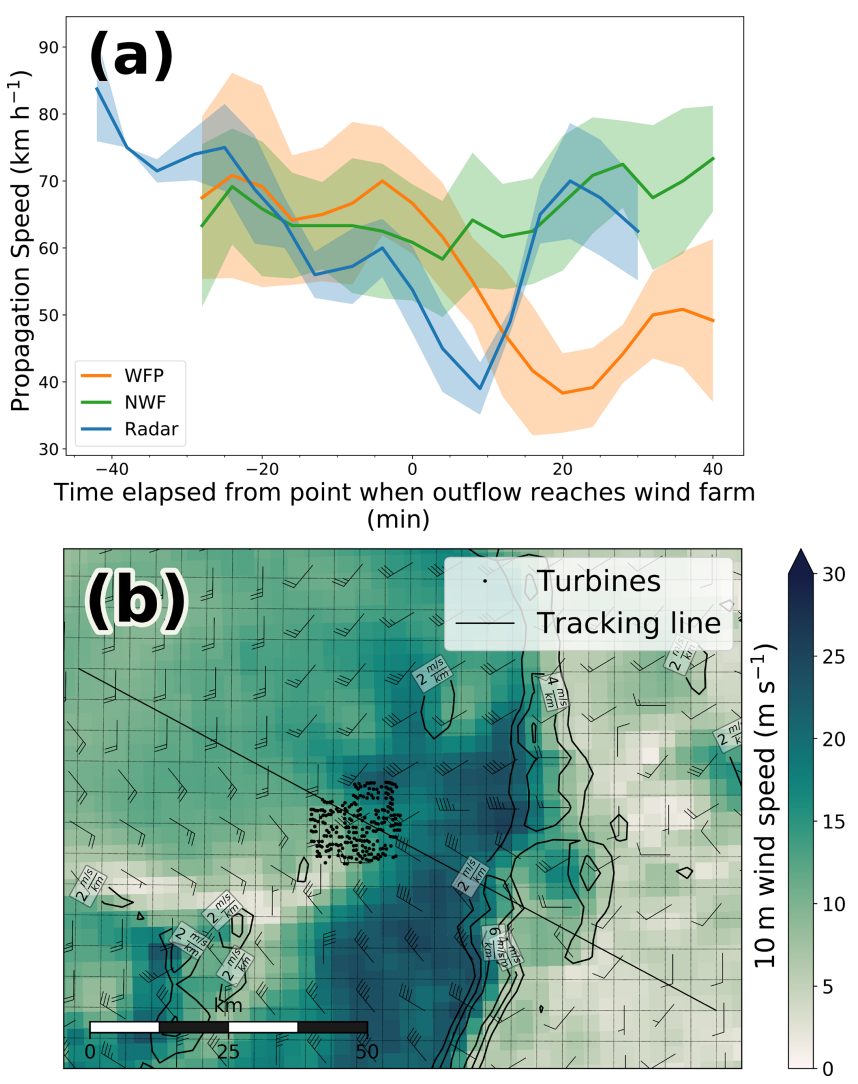

Figure 8. Plot (a) comparing the ground-relative velocity of the outflow in time between the Wind Farm Parameterization (WFP) simulation, no wind farm (NWF) simulation, and radar observations. The schematic in (b) shows the process for calculating the simulation outflow speed, where the line through the domain shows the transect along which speed was measured, with the largest gradients in $10 \mathrm{~m}$ wind speed providing the position of the boundary to track and the underlying $5 \mathrm{~km} \times 5 \mathrm{~km}$ grid providing a visual guideline to aid in tracking.

$\frac{4 \mathrm{~m} \mathrm{~s}^{-1}}{\mathrm{~km}}$ transect was chosen, the measurement tracker tried to follow that same point, even if the transect intersected the $\frac{4 \mathrm{~m} \mathrm{~s}^{-1}}{\mathrm{~km}}$ contour in multiple places. The averages of each case are plotted in Fig. 8a, around which \pm 1 standard deviation forms the shaded cloud and serves as our error bounds. As in Fig. 4 and Arthur et al. (2020), the simulation results are shifted forward $2 \mathrm{~h}$ to align with the radar results. A running average with an 8 min window was applied to all three time series to smooth the results for viewing.

As suggested in Figs. 5 and 7, speeds of both simulation cases and the radar data begin at similar values near $80 \mathrm{~km} \mathrm{~h}^{-1}$ (Fig. 8a). The simulated and observed outflows decelerate slightly as they propagate away from the source thunderstorm. When the radar outflow (blue line) encounters the wind farm, its speed reduces from $60 \mathrm{~km} \mathrm{~h}^{-1}$ to nearly $40 \mathrm{~km} \mathrm{~h}^{-1}$. The radar outflow recovers within 10 min back to $>60 \mathrm{~km} \mathrm{~h}^{-1}$ before being obscured by precipitation. Similarly, the Wind Farm Parameterization (WFP) simulation (or- 
ange line) fluctuates around $70 \mathrm{~km} \mathrm{~h}^{-1}$ until encountering the wind farm, when it then drops in speed to about $40 \mathrm{~km} \mathrm{~h}^{-1}$. The WFP simulation experiences a larger reduction in speed than observed but reaches its speed minimum $\sim 8$ min later than the observations. Additionally, the WFP simulation recovers its speed twice as slowly as the observed outflow. Such delays in the WFP outflow evolution could be artifacts of the $3 \mathrm{~km}$ model grid spacing or more likely the initial and boundary conditions. The no wind farm (NWF) simulation (green line), lacking wind farm interference, maintains a ground-relative velocity between 60 and $75 \mathrm{~km} \mathrm{~h}^{-1}$ throughout the period of interest.

\subsection{Simulated impacts of modified outflow boundary on precipitation}

Subtle but significant impacts of wind-farm-modified outflow on meteorological variables like wind speed, temperature, and moisture outlined in Sect. 3.2 prompt the question of the extent to which a wind-farm-modified outflow boundary can impact precipitation location and quantity. We address this question by integrating the total precipitation over a $100 \mathrm{~km}$ radius around the wind farm and comparing these quantities for the WFP (green line) and NWF (dashed black line) simulations every minute (Fig. 9a) and accumulated in time (Fig. 9b) over $3 \mathrm{~h}$. While the $1 \mathrm{~min}$ precipitation totals across the region differ slightly between the simulations, the total accumulated precipitation remains unchanged despite the altered outflow in the WFP case. We conclude that the introduction of roughness elements may change the distribution of the precipitation by a maximum of $\sim 1 \mathrm{~cm}$ across the domain at a single moment in time (Fig. 9a), but the overall precipitation accumulation is unaffected (Fig. 9b). Furthermore, a histogram detailing the number of $3 \mathrm{~km}$ grid cells that do experience a change in precipitation at a $1 \mathrm{~min}$ moment in time over $3 \mathrm{~h}$ due to the presence of the wind farm reveals that no single grid cell experiences a delta greater than $\pm 7 \mathrm{~mm}$, and over $93.4 \%$ of grid cells experience no change in precipitation (Fig. 10). Changes to precipitation due to the wind farm are thus both transient and localized.

\subsection{Power production at the simulated wind farm}

Given that wind farms can modify outflow and their associated meteorology, we next explore the effects an incoming outflow can have on a wind farm and its power production. Time series of the simulated $80 \mathrm{~m}$ wind speeds from all turbine-containing grid cells in the Wind Farm Parameterization (WFP) simulation indicate that several grid cells exceed the wind turbine's cutout speed $\left(25 \mathrm{~m} \mathrm{~s}^{-1}\right.$; dashed black line in Fig. 11a), most notably at 23:10 and 23:35 UTC. Winds in excess of this cutout speed force the turbines to brake their blades to prevent structural damage, halting power generation. The corresponding time series of power from turbinecontaining grid cells and the total integrated farm power
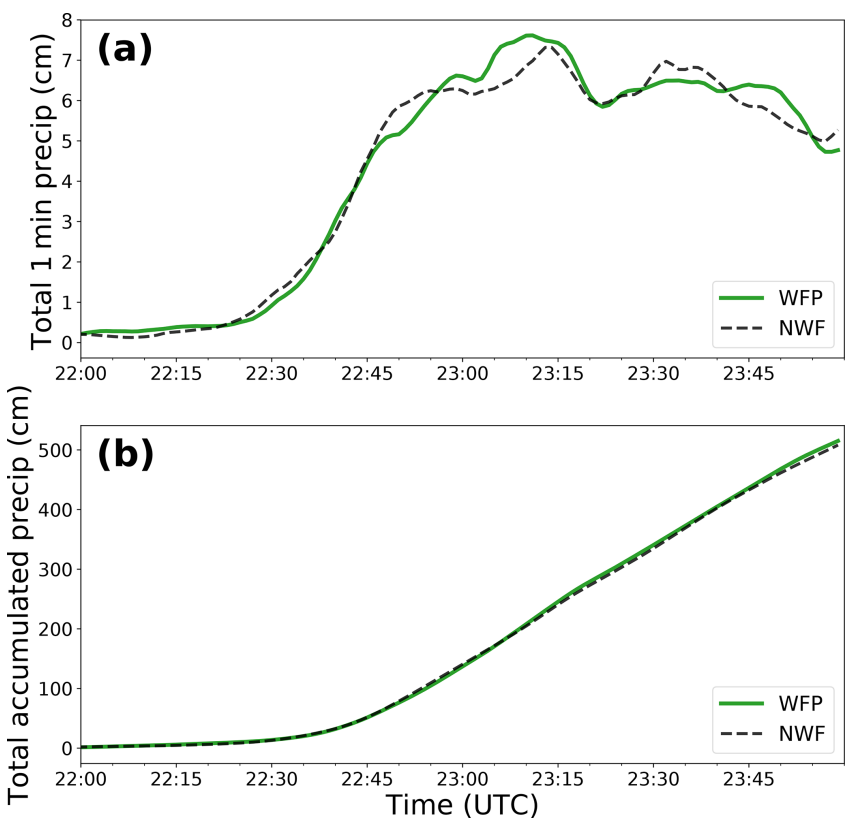

Figure 9. Time series comparing the Wind Farm Parameterization (WFP) and no wind farm (NWF) simulation solutions of (a) total 1 min precipitation and (b) total accumulated precipitation, with both quantities integrated spatially within a $100 \mathrm{~km}$ radius around the Hale wind farm.

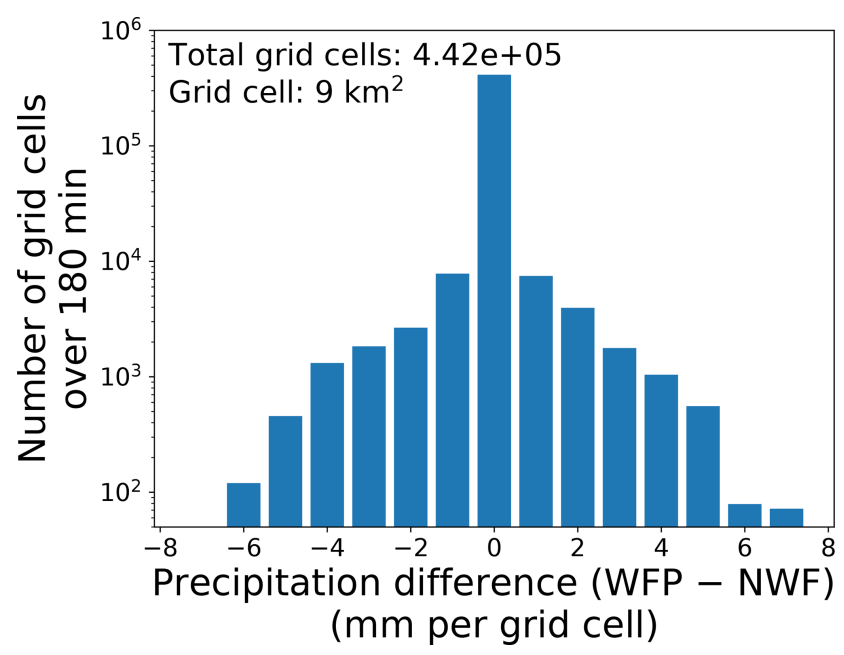

Figure 10. Histogram detailing the 1 min differences between the Wind Farm Parameterization (WFP) and no wind farm (NWF) simulations in precipitation at each grid cell within a $100 \mathrm{~km}$ radius of the Hale wind farm over 180 min.

(Fig. 11b) reflect this reduction in power during those times when the cutout wind speed is reached. Power data from the Hale wind farm are proprietary and unavailable for validation, though simulation data suggest that outflow winds are high enough to cause wind turbines to cut out and reduce total farm power generation (Fig. 11). 

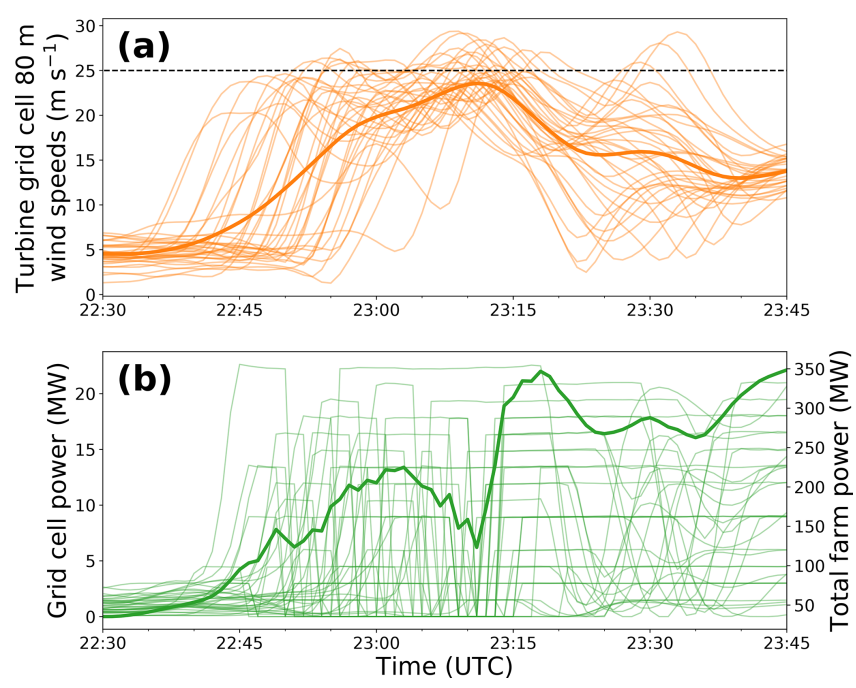

Figure 11. Time series of simulated (a) $80 \mathrm{~m}$ wind speeds from all turbine-containing grid cells (average wind speed plotted in the thicker line) and (b) power from all turbine-containing grid cells (total farm power production plotted in the thicker line) in the Wind Farm Parameterization (WFP) simulation.

\section{Discussion and conclusions}

Increasing deployment of wind energy infrastructure necessitates obtaining further knowledge on the environmental impacts of wind farms to ensure their long-term sustainability and suitability. A lower-atmospheric phenomenon not yet explored in relation to interacting with wind energy is thunderstorm outflow. Herein, we assess the impact a wind farm can have on outflow movement via observations and simulations.

We first observed wind farm impacts on outflow in NEXRAD WSR-88D radar reflectivity. On 18 June 2019, a section of an advancing outflow boundary visible on radar encountered the Hale wind farm near Lubbock, Texas, and decelerated in response. We ran two Weather Research and Forecasting (WRF) simulations to capture this event: one with a Wind Farm Parameterization (WFP) enabled and another with no wind farm present (NWF). Using observations from a West Texas Mesonet surface station, we verified that the simulations were producing reasonable solutions of the outflow event and could be used to quantify the extent to which a wind farm can modify propagating outflow.

Just as with the radar reflectivity, spatial differences between the WFP and NWF simulations exhibited a similar pattern, indicating that the wind farm slowed the progress of the outflow boundary (Figs. 1, 5). Time series of simulated surface wind speed, temperature, and moisture revealed that perturbations associated with outflow passage were delayed by up to $6 \mathrm{~min}$ when the wind farm was present in the simulation (Fig. 7). Approximations of outflow speed in the radar and simulation data confirmed that both the radarobserved and WFP simulation outflows experienced speed reductions of over $20 \mathrm{~km} \mathrm{~h}^{-1}$ after encountering the wind farm, whereas the NWF simulation maintained near-constant speed throughout the period (Fig. 8). Impacts on precipitation were minimal, with no change to total accumulation across the domain (Fig. 9). Localized shifts in precipitation location in the WFP simulation caused a maximum instantaneous grid-cell precipitation difference of $7 \mathrm{~mm} \mathrm{~km}^{-2}$, but $93.4 \%$ of grid cells within the area over the event period experienced no change in precipitation (Fig. 10).

While we have shown that a wind farm can interact with and modify thunderstorm outflow, impacts on the modified outflow speed and associated kinematic and thermodynamic variables are transient and localized. These subtle changes arising from wind farm interaction may be useful to consider when conducting nowcasting of precipitation and wind speed on a scale of a few kilometers and minutes, perhaps for aviation or other time-sensitive purposes. Impacts beyond that scale appear to be negligible.

This study uses a single known case of a wind farm interacting with outflow and is corroborated by simulations of that case. This case study could motivate a larger-scale climatology of additional outflow-wind farm interaction events, including different environments with variable soil moisture or other meteorological properties. Such a climatology could consider wind farms of different layouts and sizes as well as different turbine types and sizes to assess generalized sensitivity of atmospheric modifications to the turbine layouts and density. In previous studies (Lundquist et al., 2018), we have noticed wind farms apparently modifying the passage of frontal boundaries, so a large-scale climatology of such events, tracking frontal ground-relative velocity, could shed more light on how widespread and impactful the modification of atmospheric processes by wind farms can be.

Code and data availability. The WRF-ARW model code is publicly available at https://doi.org/10.5065/D6MK6B4K (Skamarock et al., 2008). This work uses the WRF-ARW model and the WRF Preprocessing System version 3.8.1 (released on $12 \mathrm{Au}-$ gust 2016), and the Wind Farm Parameterization is distributed therein. Initial and boundary conditions are provided by ERAInterim (Dee et al., 2011) and are available at https://rda.ucar. edu/datasets/ds627.0/. Topographic data are provided at a $30 \mathrm{~s}$ resolution from http://www2.mmm.ucar.edu/wrf/users/download/get_ source.html (Skamarock et al., 2008). The Pennsylvania State University generic $1.5 \mathrm{MW}$ turbine (Schmitz, 2012) is available at https://doi.org/10.13140/RG.2.2.22492.18567. The user input and data needed to recreate the figures and analysis are located at https://doi.org/10.5281/zenodo.3974719 (Tomaszewski, 2020).

Author contributions. JKL and JMT conceived the research and designed the WRF simulations; JMT carried out the WRF simulations and wrote the manuscript with significant input from JKL. 
Competing interests. The authors declare that they have no competing interests.

Acknowledgements. WRF simulations were conducted using the Extreme Science and Engineering Discovery Environment (XSEDE), which is supported by National Science Foundation grant number ACI1053575. We thank Jessie McDonald (@jmeso212) for identifying this event and catalyzing the interesting discourse on Twitter that inspired this research.

Financial support. This work and Jessica M. Tomaszewski were supported by an NSF Graduate Research Fellowship under grant number 1144083. Julie K. Lundquist's effort was supported by an agreement with the NREL under APUP UGA-0-41026-65.

Review statement. This paper was edited by Andrea Hahmann and reviewed by two anonymous referees.

\section{References}

Allaerts, D. and Meyers, J.: Gravity Waves and Wind-Farm Efficiency in Neutral and Stable Conditions, Bound.-Lay. Meteorol., 166, 269-299, https://doi.org/10.1007/s10546-017-0307-5, 2018.

Allaerts, D. and Meyers, J.: Sensitivity and feedback of windfarm-induced gravity waves, J. Fluid Mech., 862, 990-1028, https://doi.org/10.1017/jfm.2018.969, 2019.

Armstrong, A., Burton, R. R., Lee, S. E., Mobbs, S., Ostle, N., Smith, V., Waldron, S., and Whitaker, J.: Ground-level climate at a peatland wind farm in Scotland is affected by wind turbine operation, Environ. Res. Lett., 11, 044024 , https://doi.org/10.1088/1748-9326/11/4/044024, 2016.

Arthur, R. S., Mirocha, J. D., Marjanovic, N., Hirth, B. D., Schroeder, J. L., Wharton, S., and Chow, F. K.: Multi-Scale Simulation of Wind Farm Performance during a Frontal Passage, Atmosphere, 11, 245, https://doi.org/10.3390/atmos11030245, 2020.

Baidya Roy, S.: Can large wind farms affect local meteorology?, J. Geophys. Res., 109, D19101, https://doi.org/10.1029/2004JD004763, 2004.

Baidya Roy, S. and Traiteur, J. J.: Impacts of wind farms on surface air temperatures, P. Natl. Acad. Sci., 107, 17899-17904, https://doi.org/10.1073/pnas.1000493107, 2010.

Barrie, D. B. and Kirk-Davidoff, D. B.: Weather response to a large wind turbine array, Atmos. Chem. Phys., 10, 769-775, https://doi.org/10.5194/acp-10-769-2010, 2010.

Carbone, R. E., Conway, J. W., Crook, N. A., and Moncrieff, M. W.: The Generation and Propagation of a Nocturnal Squall Line. Part I: Observations and Implications for Mesoscale Predictability, Mon. Weather Rev., 118, 26-49, https://doi.org/10.1175/15200493(1990)118<0026:TGAPOA>2.0.CO;2, 1990.

Cervarich, M. C., Roy, S. B., and Zhou, L.: Spatiotemporal Structure of Wind Farm-atmospheric Boundary Layer Interactions, Energy Procedia, 40, 530-536, https://doi.org/10.1016/j.egypro.2013.08.061, 2013.
Christiansen, M. B. and Hasager, C. B.: Wake effects of large offshore wind farms identified from satellite SAR, Remote Sens. Environ., 98, 251-268, https://doi.org/10.1016/j.rse.2005.07.009, 2005.

Dee, D. P., Uppala, S. M., Simmons, A. J., Berrisford, P., Poli, P., Kobayashi, S., Andrae, U., Balmaseda, M. A., Balsamo, G., Bauer, P., Bechtold, P., Beljaars, A. C. M., van de Berg, L., Bidlot, J., Bormann, N., Delsol, C., Dragani, R., Fuentes, M., Geer, A. J., Haimberger, L., Healy, S. B., Hersbach, H., Hólm, E. V., Isaksen, L., Kållberg, P., Köhler, M., Matricardi, M., McNally, A. P., Monge-Sanz, B. M., Morcrette, J.-J., Park, B.-K., Peubey, C., de Rosnay, P., Tavolato, C., Thépaut, J.-N., and Vitart, F.: The ERA-Interim reanalysis: configuration and performance of the data assimilation system, Q. J. Roy. Meteorol. Soc., 137, 553-597, https://doi.org/10.1002/qj.828, 2011 (data available at: https://rda.ucar.edu/datasets/ds627.0/, last access: 20 December 2020).

Droegemeier, K. K. and Wilhelmson, R. B.: Numerical Simulation of Thunderstorm Outflow Dynamics. Part I: Outflow Sensitivity Experiments and Turbulence Dynamics, J. Atmos. Sci., 44, 1180-1210, https://doi.org/10.1175/15200469(1987)044<1180:NSOTOD>2.0.CO;2, 1987.

Duda, J. D. and Gallus, W. A.: The Impact of Large-Scale Forcing on Skill of Simulated Convective Initiation and Upscale Evolution with Convection-Allowing Grid Spacings in the WRF, Weather Forecast., 28, 994-1018, https://doi.org/10.1175/WAFD-13-00005.1, 2013.

Dudhia, J.: Numerical Study of Convection Observed during the Winter Monsoon Experiment Using a Mesoscale Two-Dimensional Model, J. Atmos. Sci., 46, 3077-3107, https://doi.org/10.1175/15200469(1989)046<3077:NSOCOD>2.0.CO;2, 1989.

ECMWF: ERA-Interim Project, Research Data Archive at the National Center for Atmospheric Research, Computational and Information Systems Laboratory, Boulder, CO, https://doi.org/10.5065/D6CR5RD9, 2009.

Ek, M. B., Mitchell, K. E., Lin, Y., Rogers, E., Grunmann, P., Koren, V., Gayno, G., and Tarpley, J. D.: Implementation of Noah land surface model advances in the National Centers for Environmental Prediction operational mesoscale Eta model, J. Geophys. Res.-Atmos., 108, 2002JD003296, https://doi.org/10.1029/2002JD003296, 2003.

Fitch, A. C.: Climate Impacts of Large-Scale Wind Farms as Parameterized in a Global Climate Model, J. Climate, 28, 6160-6180, https://doi.org/10.1175/JCLI-D-14-00245.1, 2015.

Fitch, A. C.: Notes on using the mesoscale wind farm parameterization of Fitch et al. (2012) in WRF, Wind Energ., 19, 1757-1758, https://doi.org/10.1002/we.1945, 2016.

Fitch, A. C., Olson, J. B., Lundquist, J. K., Dudhia, J., Gupta, A. K., Michalakes, J., and Barstad, I.: Local and Mesoscale Impacts of Wind Farms as Parameterized in a Mesoscale NWP Model, Mon. Weather Rev., 140, 3017-3038, https://doi.org/10.1175/MWRD-11-00352.1, 2012.

Fitch, A. C., Lundquist, J. K., and Olson, J. B.: Mesoscale Influences of Wind Farms throughout a Diurnal Cycle, Mon. Weather Rev., 141, 2173-2198, https://doi.org/10.1175/MWRD-12-00185.1, 2013.

Frandsen, S. T., Jørgensen, H. E., Barthelmie, R., Rathmann, O., Badger, J., Hansen, K., Ott, S., Rethore, P.-E., Larsen, S. E., 
and Jensen, L. E.: The making of a second-generation wind farm efficiency model complex, Wind Energ., 12, 445-458, https://doi.org/10.1002/we.351, 2009.

Goff, R. C.: Vertical Structure of Thunderstorm Outflows, Monthly Weather Review, 104, 1429-1440, https://doi.org/10.1175/15200493(1976)104<1429:VSOTO>2.0.CO;2, 1976.

Hoen, B., Diffendorfer, J., Rand, J., Kramer, L., Garrity, C., and Hunt, H.: United States Wind Turbine Database, available at: https://eerscmap.usgs.gov/uswtdb (last access: 20 December 2020), 2020.

Hong, S. and Lim, J. J.: The WRF Single-Moment 6-Class Microphysics Scheme (WSM6), Asia-pacific Journal of Atmospheric Sciences, 42, 129-151, 2006.

Hunter, J. D.: Matplotlib: A 2D graphics environment, Comput. Sci. Eng., 9, 90-95, https://doi.org/10.1109/MCSE.2007.55, 2007.

IEA: World Energy Outlook 2018, available at: https://www.iea. org/reports/world-energy-outlook-2018 (last access: 20 December 2020), 2018.

Isom, B. M., Palmer, R. D., Secrest, G. S., Rhoton, R. D., Saxion, D., Allmon, T. L., Reed, J., Crum, T., and Vogt, R.: Detailed Observations of Wind Turbine Clutter with Scanning Weather Radars, J. Atmos. Ocean. Tech., 26, 894-910, https://doi.org/10.1175/2008JTECHA1136.1, 2009.

Jimenez, P. A., Dudhia, J., González-Rouco, J. F., Navarro, J., Montávez, J. P., and García-Bustamante, E.: A Revised Scheme for the WRF Surface Layer Formulation, Mon. Weather Rev., 140, 898-918, https://doi.org/10.1175/MWR-D-11-00056.1, 2012.

Kain, J. S.: The Kain-Fritsch Convective Parameterization: An Update, J. Appl. Meteorol., 43, 170-181, https://doi.org/10.1175/15200450(2004)043<0170:TKCPAU>2.0.CO;2, 2004.

Keith, D. W., DeCarolis, J. F., Denkenberger, D. C., Lenschow, D. H., Malyshev, S. L., Pacala, S., and Rasch, P. J.: The influence of large-scale wind power on global climate, P. Natl. Acad. Sci., 101, 16115-16120, https://doi.org/10.1073/pnas.0406930101, 2004.

Klazura, G. E. and Imy, D. A.: A Description of the Initial Set of Analysis Products Available from the NEXRAD WSR-88D System, B. Am. Meteorol. Soc., $\quad 74, \quad 1293-1312$, https://doi.org/10.1175/15200477(1993)074<1293:ADOTIS>2.0.CO;2, 1993.

Klingle, D. L., Smith, D. R., and Wolfson, M. M.: Gust Front Characteristics as Detected by Doppler Radar, Mon. Weather Rev., 115, 905-918, https://doi.org/10.1175/15200493(1987)115<0905:GFCADB>2.0.CO;2, 1987.

Lee, J. C. Y. and Lundquist, J. K.: Evaluation of the wind farm parameterization in the Weather Research and Forecasting model (version 3.8.1) with meteorological and turbine power data, Geosci. Model Dev., 10, 4229-4244, https://doi.org/10.5194/gmd-10-4229-2017, 2017a.

Lee, J. C. Y. and Lundquist, J. K.: Observing and Simulating WindTurbine Wakes During the Evening Transition, Bound.-Lay. Meteorol., 164, 449-474, https://doi.org/10.1007/s10546-017-0257y, 2017b.

Lissaman, P. B. S.: Energy Effectiveness of Arbitrary Arrays of Wind Turbines, J. Energy, 3, 323-328, https://doi.org/10.2514/3.62441, 1979.

Lundquist, J. K., DuVivier, K. K., Kaffine, D., and Tomaszewski, J. M.: Costs and consequences of wind turbine wake effects arising from uncoordinated wind energy development, Nature Energy, 4, 26-34, https://doi.org/10.1038/s41560-018-0281-2, 2018.

Mlawer, E. J., Taubman, S. J., Brown, P. D., Iacono, M. J., and Clough, S. A.: Radiative transfer for inhomogeneous atmospheres: RRTM, a validated correlated-k model for the longwave, J. Geophys. Res.-Atmos., 102, 16663-16682, https://doi.org/10.1029/97JD00237, 1997.

Mueller, C. K. and Carbone, R. E.: Dynamics of a Thunderstorm Outflow, Journal of the Atmospheric Sciences, 44, 1879-1898, https://doi.org/10.1175/15200469(1987)044<1879:DOATO>2.0.CO;2, 1987.

Nakanishi, M. and Niino, H.: An Improved Mellor-Yamada Level3 Model: Its Numerical Stability and Application to a Regional Prediction of Advection Fog, Bound.-Lay. Meteorol., 119, 397407, https://doi.org/10.1007/s10546-005-9030-8, 2006.

NOAA National Weather Service, R. O. C.: NOAA Next Generation Radar (NEXRAD) Level II Base Data, https://doi.org/10.7289/V5W9574V, type: dataset, 1991.

Nugraha, A. A. A. and Trilaksono, N. J.: Simulation of wind gust - Producing thunderstorm outflow over Mahakam block using WRF, AIP Conference Proceedings, 1987, 020051, https://doi.org/10.1063/1.5047336, 2018.

Platis, A., Siedersleben, S. K., Bange, J., Lampert, A., Bärfuss, K., Hankers, R., Cañadillas, B., Foreman, R., Schulz-Stellenfleth, J., Djath, B., Neumann, T., and Emeis, S.: First in situ evidence of wakes in the far field behind offshore wind farms, Scientific Reports, 8, 2163, https://doi.org/10.1038/s41598-018-20389-y, 2018.

Powers, J. G., Klemp, J. B., Skamarock, W. C., Davis, C. A., Dudhia, J., Gill, D. O., Coen, J. L., Gochis, D. J., Ahmadov, R., Peckham, S. E., Grell, G. A., Michalakes, J., Trahan, S., Benjamin, S. G., Alexander, C. R., Dimego, G. J., Wang, W., Schwartz, C. S., Romine, G. S., Liu, Z., Snyder, C., Chen, F., Barlage, M. J., Yu, W., and Duda, M. G.: The Weather Research and Forecasting Model: Overview, System Efforts, and Future Directions, B. Am. Meteorol. Soc., 98, 1717-1737, https://doi.org/10.1175/BAMSD-15-00308.1, 2017.

Quan, W., Xu, X., and Wang, Y.: Observation of a straightline wind case caused by a gust front and its associated fine-scale structures, J. Meteorol. Res., 28, 1137-1154, https://doi.org/10.1007/s13351-014-3080-0, 2014.

Rajewski, D. A., Takle, E. S., Lundquist, J. K., Oncley, S., Prueger, J. H., Horst, T. W., Rhodes, M. E., Pfeiffer, R., Hatfield, J. L., Spoth, K. K., and Doorenbos, R. K.: Crop Wind Energy Experiment (CWEX): Observations of Surface-Layer, Boundary Layer, and Mesoscale Interactions with a Wind Farm, B. Am. Meteorol. Soc., 94, 655-672, https://doi.org/10.1175/BAMS-D11-00240.1, 2013.

Rajewski, D. A., Takle, E. S., Lundquist, J. K., Prueger, J. H., Pfeiffer, R. L., Hatfield, J. L., Spoth, K. K., and Doorenbos, R. K.: Changes in fluxes of heat, $\mathrm{H} 2 \mathrm{O}$, and $\mathrm{CO} 2$ caused by a large wind farm, Agr. Forest Meteorol., 194, 175-187, https://doi.org/10.1016/j.agrformet.2014.03.023, 2014.

Rajewski, D. A., Takle, E. S., Prueger, J. H., and Doorenbos, R. K.: Toward understanding the physical link between turbines and microclimate impacts from in situ measurements in a large wind farm: Microclimate With Turbines 
ON Versus OFF, J. Geophys. Res.-Atmos., 121, 13392-13414, https://doi.org/10.1002/2016JD025297, 2016.

Rajewski, D. A., Takle, E. S., VanLoocke, A., and Purdy, S. L.: Observations Show That Wind Farms Substantially Modify the Atmospheric Boundary Layer Thermal Stratification Transition in the Early Evening, Geophys. Res. Lett., 47, https://doi.org/10.1029/2019GL086010, 2020.

Redfern, S., Olson, J. B., Lundquist, J. K., and Clack, C. T. M.: Incorporation of the Rotor-Equivalent Wind Speed into the Weather Research and Forecasting Model's Wind Farm Parameterization, Mon. Weather Rev., 147, 1029-1046, https://doi.org/10.1175/MWR-D-18-0194.1, 2019.

Schmitz, S.: XTurb-PSU: A Wind Turbine Design and Analysis Tool, https://doi.org/10.13140/RG.2.2.22492.18567, 2012.

Schroeder, J. L., Burgett, W. S., Haynie, K. B., Sonmez, I., Skwira, G. D., Doggett, A. L., and Lipe, J. W.: The West Texas Mesonet: A Technical Overview, J. Atmos. Ocean. Tech., 22, 211-222, https://doi.org/10.1175/JTECH-1690.1, 2005.

Siedersleben, S. K., Lundquist, J. K., Platis, A., Bange, J., Bärfuss, K., Lampert, A., Cañadillas, B., Neumann, T., and Emeis, S.: Micrometeorological impacts of offshore wind farms as seen in observations and simulations, Environ. Res. Lett., 13, 124012, https://doi.org/10.1088/1748-9326/aaea0b, 2018a.

Siedersleben, S. K., Platis, A., Lundquist, J. K., Lampert, A., Bärfuss, K., Cañadillas, B., Djath, B., Schulz-Stellenfleth, J., Bange, J., Neumann, T., and Emeis, S.: Evaluation of a Wind Farm Parametrization for Mesoscale Atmospheric Flow Models with Aircraft Measurements, Meteorol. Z., 27, 401-415, https://doi.org/10.1127/metz/2018/0900, 2018b

Siedersleben, S. K., Platis, A., Lundquist, J. K., Djath, B., Lampert, A., Bärfuss, K., Cañadillas, B., Schulz-Stellenfleth, J., Bange, J., Neumann, T., and Emeis, S.: Turbulent kinetic energy over large offshore wind farms observed and simulated by the mesoscale model WRF (3.8.1), Geosci. Model Dev., 13, 249268, https://doi.org/10.5194/gmd-13-249-2020, 2020.

Skamarock, W. C. and Klemp, J. B.: A time-split nonhydrostatic atmospheric model for weather research and forecasting applications, J. Comput. Phys., 227, 3465-3485, https://doi.org/10.1016/j.jcp.2007.01.037, 2008.

Smith, C. M., Barthelmie, R. J., and Pryor, S. C.: In situ observations of the influence of a large onshore wind farm on near-surface temperature, turbulence intensity and wind speed profiles, Environ. Res. Lett., 8, 034006, https://doi.org/10.1088/1748-9326/8/3/034006, 2013.

Skamarock, W. C., Klemp, J. B., Dudhia, J., Gill, D. O., Barker, D. M., Duda, M. G., Huang, X.-Y., Wang, W., and Powers, J. G.: A Description of the Advanced Research WRF Version 3, NCAR Tech. Note NCAR/TN-475+STR, 113 pp., https://doi.org/10.5065/D68S4MVH, 2008 (data available at: https://doi.org/10.5065/D6MK6B4K and http://www2.mmm. ucar.edu/wrf/users/download/get_source.html, last access: December 2020).
Smith, R. B.: Gravity wave effects on wind farm efficiency, Wind Energ., 13, 449-458, https://doi.org/10.1002/we.366, 2009.

Tomaszewski, J. M.: jessica-tomaszewski/WRF-WFP-outflow v1.1 (Version 1.1), Zenodo, https://doi.org/10.5281/zenodo.3974719, 2020 .

Tomaszewski, J. M. and Lundquist, J. K.: Simulated wind farm wake sensitivity to configuration choices in the Weather Research and Forecasting model version 3.8.1, Geosci. Model Dev., 13, 2645-2662, https://doi.org/10.5194/gmd-13-26452020, 2020.

Tomaszewski, J. M., Lundquist, J. K., Churchfield, M. J., and Moriarty, P. J.: Do wind turbines pose roll hazards to light aircraft?, Wind Energ. Sci., 3, 833-843, https://doi.org/10.5194/wes-3833-2018, 2018.

Toms, B. A., Tomaszewski, J. M., Turner, D. D., and Koch, S. E.: Analysis of a Lower-Tropospheric Gravity Wave Train Using Direct and Remote Sensing Measurement Systems, Mon. Weather Rev., 145, 2791-2812, https://doi.org/10.1175/MWRD-16-0216.1, 2017.

Wakimoto, R. M.: The Life Cycle of Thunderstorm Gust Fronts as Viewed with Doppler Radar and Rawinsonde Data, Mon. Weather Rev., 110, 1060-1082, https://doi.org/10.1175/15200493(1982)110<1060:TLCOTG>2.0.CO;2, 1982.

Xia, G., Zhou, L., Freedman, J. M., Roy, S. B., Harris, R. A., and Cervarich, M. C.: A case study of effects of atmospheric boundary layer turbulence, wind speed, and stability on wind farm induced temperature changes using observations from a field campaign, Clim. Dynam., 46, 2179-2196, https://doi.org/10.1007/s00382-015-2696-9, 2016.

Xia, G., Cervarich, M. C., Roy, S. B., Zhou, L., Minder, J. R., Jimenez, P. A., and Freedman, J. M.: Simulating Impacts of Real-World Wind Farms on Land Surface Temperature Using the WRF Model: Validation with Observations, Mon. Weather Rev., 145, 4813-4836, https://doi.org/10.1175/MWRD-16-0401.1, 2017.

Xia, G., Zhou, L., Minder, J. R., Fovell, R. G., and Jimenez, P. A.: Simulating impacts of real-world wind farms on land surface temperature using the WRF model: physical mechanisms, Clim. Dynam., 53, 1723-1739, https://doi.org/10.1007/s00382019-04725-0, 2019.

Zhou, L., Tian, Y., Baidya Roy, S., Thorncroft, C., Bosart, L. F., and $\mathrm{Hu}, \mathrm{Y}$.: Impacts of wind farms on land surface temperature, Nature Clim. Change, 2, 539-543, https://doi.org/10.1038/nclimate1505, 2012.

Zrnic, D. S. and Lee, J. T.: Investigation of the Detectability and Lifetime of Gust Fronts and Other Weather Hazards to Aircraft., Tech. rep., NATIONAL OCEANIC AND ATMOSPHERIC ADMINISTRATION NORMAN OK NATIONAL SEVERE STORMS LAB, available at: https://apps.dtic.mil/ dtic/tr/fulltext/u2/a141552.pdf (last access: 20 December 2020), 1983. 